\title{
EXTENSION OF NON-RESIDENT MOTORIST STATUTES TO NON-RESIDENT PERSONAL REPRESENTATIVES
}

\section{Harold Wright Holt $\dagger$}

\section{INTRODUCTION}

When the use of motor vehicles for pleasure as well as business became widespread, the demand arose for an effective method of subjecting the owner of a motor vehicle to the judicial power of a state in which he was a non-resident, but in which his operation of the vehicle had caused injury to the body or property of another. All too often, by the time the injured person was able to start suit the non-resident motorist had left the state. The injured person wished to sue in the state in which he had been damaged and in which he might be a resident. $^{1}$ In that state, however, the injuring motorist was not present to be served with process; nor would he voluntarily appear in any action instituted against him there. What has happened?

The state of injury, State $X$, to prevent similar cases of hardship from arising in the future, enacts a statute. The statute provides that a non-resident of the state who operates a motor vehicle on its highways is deemed to appoint some official of State $X$ as his agent for the service of process in any action brought in a State $X$ court by a plaintiff claiming injury by reason of the non-resident's operation of the vehicle on the highways in State $\mathrm{X}$ and seeking compensation therefor. ${ }^{2}$ In support of the statute it may be said that the non-resident of State $\mathrm{X}$ by operating a motor vehicle on a highway of that state assents in advance to that state's exercise of judicial power over him to the limited extent just indicated. ${ }^{3}$ It appears to even a moderately skeptical mind that the argument assumes as true that which is not. The legislation, nevertheless, is valid, provided the statute requires a method of notification to the non-resident of the institution of action

$\dagger$ A. B., 1917, Dartmouth College; LI. B., 1920, S. J. D., 1928, Harvard University. Professor of Law, University of Illinois College of Law.

1. Unless otherwise indicated, in this article "resident" is synonymous with "domiciliary" and "residence" with "domicile."

2. E.g., ILt. AnN. StaT. c. 951/2, §23 (1950); Ind. ANN. Stat. tit. 8, §471043 (Burns Cum. Supp. 1951).

3. Hess v. Pawloski, 274 U.S. 352 (1927). 
that is considered to meet the requirements of due process. ${ }^{4}$ A non sequitur in reasoning reaches a desired-and possibly a desirableconclusion.

There are drawbacks in this mode of the development of the law. A court may fail to realize that the extension of a commonly-held or long-accepted concept or theory to a new field of application is only plausible, and therefore feel unable to countenance an additional and desirable development in the law because it accepts at face value the plausible rationalization employed to justify the earlier advance.

It is reasonable that $D$, a resident of State $F$, who so operates his automobile on the highways of State $X$ as to injure the person or property of a plaintiff should be held to answer to him in a State $X$ court even though $D$ may have left State $X$ before the plaintiff could institute judicial action. Of course $\mathrm{D}$ should be given the best possible notice of the institution of any action by the plaintiff. But why seek to justify the exercise of State X's judicial power by resort to an unsound and untrue theory of assent thereto by $D$ ?

What may happen if a court of State $X$ does do so? Suppose that $D$ dies before plaintiff brings any suit. May A, D's lawfully appointed domiciliary (State $F$ ) personal representative, ${ }^{5}$ be made a party defendant in an action in State $X$ by substituted service similar to that which could have been had on $D$ in his lifetime under the State X NonResident Motorist Statute? Several legislatures have so enacted. ${ }^{6}$ If, however, the State $X$ court accepts at face value, as in accord with the realities of life, the theory that $D$ had by use of State $X$ highways for the operation of his motor vehicle assented to the appointment of the designated official of State $X$ as his agent for the receipt of service of process, the court may hold that D's death terminated the agency, and that A cannot be brought before the court in State $\mathrm{X}$ by a mode of service that would have sufficed to subject $D$ in his lifetime to the judicial power of State X.

It is even more likely that this conclusion will be reached if the court in State $\mathrm{X}$ adheres to the theory that a personal representative of $D$ lawfully appointed in State $F$, the state in which $D$ was domiciled

4. See Wuchter v. Pizzutti, 276 U.S. 13 (1928).

5. Unless otherwise indicated, in this article a "personal representative" may be either an administrator or executor. However the legal relations of an administrator may be distinguished from those of an executor, there is no material difference between the two for the purposes of our discussion. See RESTATEMrENT, CoNfrict of LAws, Introductory Note at 559, 560 (1934) and Note, 36 IowA L. REv. 668, 672-674 (1951).

6. E.g.; N.Y. Vehicle \& Traffic LAw, §52.

7. See cases cited in Knoop v. Anderson, 71 F. Supp. 832, 847 et seq. (N.D. Iowa 1947). Contra: Feinsinger v. Bard, 195 F.2d 45 (7th Cir. 1952); Oviatt v. Garretson, 205 Ark. 792, 171 S.W.2d 287 (1943) ; Plopa v. DuPre, 327 Mich. 660, 42 N.W.2d 777 (1950); Leighton v. Roper, 300 N.Y. 434, 91 N.E.2d 876 (1950). 
at death, is immune from suit outside the state of his appointment. $A$ is appointed personal representative in State $F$ to do certain tasks: to collect assets that belonged to $\mathrm{D}$ and that are within the competency of State $F$ to administer, to pay off claims proved against the assets, and ultimately to distribute the balance that may remain among those entitled under the law of State $F .^{8}$ It may well be that in many cases State $\mathrm{X}$ should refuse to allow action against one who has been appointed personal representative in State F; for if it were to allow such actions, State $X$ would fail to pay due regard to the superior interest of State $F$ as the state of administration.

But may there not be instances where State $F$ should be forced to recognize that State $X$ has an interest superior to any of its own-an interest so superior that State $F$ will be forced to give recognition to a judgment of a State $X$ court against $A$, as D's personal representative, by accepting such judgment as a claim against assets of D's estate in State F? May not such recognition by State F of the State X judgment be compelled under the full faith and credit clause ${ }^{9}$ May there not be cases where a personal representative of $D$, lawfully appointed in State F, should be brought before the court in State $X$ through substituted service on some state official of $X$ ? It is the purpose of this article to show that these questions can and should reasonably be answered in the affirmative.

\section{The Applicability of Full Faith and Credit to Statutes Dealing With Tort Liability}

Congress has recently decreed that acts of the legislature of a state, when duly authenticated, "shall have the same full faith and credit in every court within the United States and its Territories and Possessions as they have by law or usage in the courts of such State . . . from which they are taken." 10 At long last public acts have been put on the same footing as court judgments so far as the wording of federal legislation implementing the full faith and credit clause is concerned.

Of course, the question whether a judgment-even though valid within the state of rendition-is entitled to external recognition in a sister state under the full faith and credit clause, as an adjudication of a right-duty relation, is one for the Supreme Court to answer. ${ }^{11}$ Like(1934).

8. See Restatenent, Conflict of Laws, Introductory Note at 559 et seq.

9. U.S. Const. Art. IV, § 1.

10. 28 U.S.C. $\$ 1738$ (Supp. 1950).

11. See statements of $\mathrm{Mr}$. Chief Justice Stone in Magnolia Petroleum Co. v. Hunt, 320 U.S. 430,438 (1943). 
wise, whether a statute of a state is to be given external recognition in courts of sister states must be a matter for that Court to decide. ${ }^{12}$

It would be a work of supererogation to argue that the application of the full faith and credit clause to state statutes must be more flexible than the application of the clause to state court judgments.

"Prima facie every state is entitled to enforce in its own courts its own statutes, lawfully enacted. One who challenges that right, because of the force given to a conflicting statute of another state by the full faith and credit clause, assumes the burden of showing, upon some rational basis, that of the conflicting interests involved those of the foreign state are superior to those of the forum. It follows that not every statute of another state will override a conflicting statute of the forum by virtue of the full faith and credit clause; that the statute of a state may sometimes override the conflicting statute of another, both at home and abroad; and, again, that the two conflicting statutes may each prevail over the other at home, although given no extraterritorial effect in the state of the other." 13

In other words, the public policy of one state as expressed in its statute may conflict with the public policy of a sister state as set forth in its legislation. Then the Supreme Court must act as arbitrator by making a selection between the competing public policies involved. ${ }^{14}$ The demand for the rendition of full faith and credit to a state statute may, however, present a somewhat different problem. The question posed to the Supreme Court may be: should the policy of one state, whether or not expressed in statutory form, yield to a national or federal policy that favors recognition and enforcement throughout the United States, its territories and possessions, of right-duty relations arising under the statute of any one of the other states? ${ }^{15}$

Under the full faith and credit clause, a state may be compelled to recognize a right of action in a plaintiff because of a statute of a sister state. Almost twenty years ago a defendant in an action in the United States District Court in New Hampshire defeated a plaintiff administratrix who sought recovery under a New Hampshire statute for the negligent killing in that state of her intestate. ${ }^{10}$ Defendant succeeded by convincing the Supreme Court that full faith and credit was due in New Hampshire to a provision in the Vermont Workmen's Compensation Act purporting to make the remedy provided by

12. Hughes v. Fetter, 341 U.S. 609, 611 (1951). (1935).

13. Alaska Packers Ass'n v. Industrial Acc. Comm., 294 U.S. 532, 547-548

14. Hughes v. Fetter, 341 U.S. 609, 611-612 (1951).

15. Ibid.

16. Bradford Electric Light Co. v. Clapper, 286 U.S. 145 (1932). 
that statute "exclusive". of any other remedy. ${ }^{17}$ At that time the Supreme Court might have been hesitant to rule that full faith and credit required a state to recognize a tort right of action in a plaintiff created under the statute of a sister state. ${ }^{18}$ Recently, however, the Court decided Hughes $v$. Fetter. ${ }^{19}$ The legislation of Wisconsin allowed actions in its courts for the recovery of compensation for the wrongful killing of a deceased only when the act causing death occurred in Wisconsin. ${ }^{20}$ Accordingly, a plaintiff administrator had not been allowed to prosecute an action for the alleged wrongful killing of his intestate in Illinois. ${ }^{21}$ The Supreme Court, however, held on appeal that Wisconsin could not refuse access to its courts for enforcement of the cause of action under the wrongful death act of Illinois, ${ }^{22}$ saying that "Wisconsin's statutory policy which excludes this Illinois cause of action is forbidden by the national policy of the Full Faith and Credit Clause." 23

There is no need here to discuss the significance of the decision and the reasoning in the opinions of the majority of the Court and of the four dissenting justices. ${ }^{24}$ It may be conceded that not every statute creating tort liability will be entitled to external recognition under the full faith and credit clause, but it is material to consider whether, and to what extent, a statute providing for survival of tort liability is entitled to be so recognized.

\section{The Application of Full Faith and Credit to Statutes Providing for Survival of Tort Liability}

It is not contended that a statute of survival always merits full faith and credit. For example, suppose that $D$, a resident of State F, makes statements while he is present in State $X$ which, under the circumstances, constitute under the law of State $\mathrm{X}$ a cause of action in defamation in favor of $P$ and that $D$ dies before $P$ sues. Suppose, further, that a statute of State $X$ permits causes of action in tort for defamation to survive. Should State $F$ be held under a duty to give

17. VT. GEN. Laws $\$ 5774$ (1917), now VT. REV. STat. $\$ 8076$ (1947).

18. Compare language of Mr. Justice Brandeis in Bradford Electric Light Co. v. Clapper, 286 U.S. 145, 160 (1932), with language of Mr. Justice Stone in the same case, id. at 163.

19. 341 U.S. 609 (1951). See also First Natl. Bank v. United Air Lines, Inc., 342 U.S. 396 (1952).

20. WIS. STAT. $\$ 331.03$ (1949).

21. Hughes v. Fetter, 257 Wis. 35, 42 N.W.2d 452 (1950). 1951).

22. Ily. Ann. Stat. c. 70, §2 (1936), now Ir.. Ann. Stat. c. 70, 2 (Supp.

23. Hughes v. Fetter, 341 U.S. 609, 613 (1951).

24. Mr. Justice Frankfurter delivered a dissenting opinion in which Mr. Justice Jackson, Mr. Justice Minton and Mr. Justice Reed joined. 
full faith and credit to that statute of State $X$ by allowing a right of action in favor of $P$ against the personal representative of $D$ lawfully appointed in State $F$ ? There may be good reason for giving a negative answer. With the possible exception of radio broadcasters, it is not unreasonable to believe that a person is far less apt to commit the tort of defamation away from the state of his residence than he is to injure, away from the state of his residence, the body or property of another by negligent operation of a motor vehicle. ${ }^{25}$ It is even more reasonable to believe that a person is less apt to die outside of the state of his residence as a consequence of his defamatory utterances than he is to die as a consequence of his negligent operation of a motor vehicle in a state other than the state of his residence. On the other hand, each of the forty-eight states has a strong governmental interest in securing reparation to persons injured within its borders by the negligent driving of non-resident motorists. The harmonious working of our federal system requires the adequate implementation of such state interest. ${ }^{26}$ Accordingly, it is reasonable to contend that considerations of national policy justify the extension of full faith and credit to statutes of survival so far as they apply to actions in tort for personal injuries caused by automobile accidents.

Case 1. $\mathrm{P}$, while driving his automobile on the public highways of State $X$, was injured in a collision with a car driven by $D$, a resident of State F. D was at fault; $P$ exercised due care. Before $P$ sues, D dies possessed of an estate within the competency of State $F$ to administer. A is duly appointed D's personal representative in State F, which has a statute permitting actions in tort for injuries to the person to survive the death of a tort-feasor. State $X$ has no such statute. In that state in "local" or "domestic" cases the courts hold that liability in tort does not survive the death of a wrongdoer. May $P$ sue $A$ in a court of State $F$ ?

In a leading case Chase claimed to have been injured by the negligent operation of an elevator in a New York building owned by Ormsby, a resident of Pennsylvania. Chase might have recovered a judgment against Ormsby in his lifetime if she had sued him in New York or in Pennsylvania. She brought no action against him in his lifetime, but after his death brought suit in the United States District Court for the Eastern District of Pennsylvania against Ormsby's executor, relying upon a Pennsylvania statute making an executor liable (1927).

25. See statement of Mr. Justice Butler in Hess v. Pawloski, 274 U.S. 352, 356

26. See statement of Mr. Justice Brandeis in Young v. Masci, 289 U.S. 253, 259 et seq. (1933). 
to suit in any action which might have been brought against the deceased during life. ${ }^{27}$ In New York, seemingly, she could not, after Ormsby's death, have maintained action against his personal representative, even though the latter had been duly appointed and qualified under the law of New York. The court entered a compulsory nonsuit against Chase. ${ }^{28}$ The Circuit Court of Appeals reversed and awarded a venire facias de novo. ${ }^{29}$ The Supreme Court of the United States, on certiorari, reversed the Circuit Court of Appeals. ${ }^{30}$

The Supreme Court of Pennsylvania had already held that the Pennsylvania statute permitting actions in tort to survive against the personal representative of a wrongdoer did not apply to actions for personal injuries sustained outside of Pennsylvania. In Sumner $v$. Browe $^{31}$ two residents of Pennsylvania had been partners. One of them in the course of firm business drove an automobile in New York so recklessly as to kill himself and to injure the plaintiff, his guest. The surviving partner, Arthur, later died. Still later the plaintiff brought action against the executrix of Arthur in trespass for personal injuries. Judgment for the defendant executrix on the pleadings was affirmed because the plaintiff had failed to allege in his statement of claim that the law of New York provided for survivability, against the estate of a decedent; of liability for a common law cause of action. The court said: "Unless the law of New York provided a right of action for the tort, none exists; without a right of action, the suit must fail; if a right exists, it must be pleaded. . . ." 32

The Federal Rules of Decision Act $^{33}$ requires federal courts in Pennsylvania in cases within the diversity of citizenship jurisdiction to enforce applicable statutes of Pennsylvania as interpreted and construed by the highest court of the Commonwealth, provided, of course, such statutes violate no part of the Constitution of the United States. In the light of this Act and of Sumner v. Brown, it is difficult to see how in the Chase case the Supreme Court could have done otherwise than reverse the Circuit Court of Appeals. The opinion of the Circuit Court of Appeals did not mention Sumner v. Brown, but Mr. Justice Butler, who delivered the majority opinion for the Supreme Court, was aware of it. $^{34}$

27. PA. Stat. Ann. tit. 20, $\$ 772$ (Purdon 1930), repealed, P.L. 512, §1401 (1949).

28. Chase v. Ormsby, 3 F. Supp. 680 (E.D. Pa. 1931).

29. Chase v. Ormsby, 65 F.2d 521 (3d Cir. 1933).

30. Ormsby v. Chase, 290 U.S. 387 (1933).

31. $312 \mathrm{~Pa} .124,167$ Atl. 315 (1933).

32. 312 Pa. 124, 127, 167 Atl. 315, 316 (1933).

33. 28 U.S.C. \$1652 (1948).

34. He cited the case in his opinion. 
The Circuit Court of Appeals seems to have been of the opinion that no state had a stronger interest than Pennsylvania in deciding what disposal should be made of Ormsby's assets within its jurisdiction to administer. According to that court, survivability of a cause of action in tort for negligence was to be determined by the court of the domicile at death of the tort-feasor without regard to the law of the state in which the negligent conduct inflicted injury:

"State legislatures have absolute dominion over the property or estate of dead men and determine what causes of action survive and what abate with their death. Whether or not a cause of action survives is, therefore, determined by laws of the state where the action is brought and not by the laws of the state in which the injury is inflicted." 3

Mr. Justice Butler does not refer to this statement of the Circuit Court of Appeals, but he certainly does not agree with it. According to him, "the law of the place of the wrong determines whether the claim for damages survives the death of the wrongdoer." 36 And "the place of wrong" was the state in which Chase suffered injury.

In our hypothetical case, then, Ormsby v. Chase would not allow $P$ to recover in an action in State $F$ against $A$ as $D$ 's administrator.

Case 2. Suppose the facts to be as in case 1, with this difference: State $\mathrm{X}$ has the survival statute, but State $\mathrm{F}$ adheres to the commonlaw rule. May $P$ maintain an action in State $F$ against $A$ as D's personal representative?

Quite properly the Court in Ormsby v. Chase gives no indication as to what the answer would be. Since that case, however, there have been decisions in the lower federal courts that deny $\mathrm{P}$ a right of action unless the law of the state in which $P$ receives his injury and the law of the state in which he sues D's personal representative permit a cause of action in tort for personal injuries to survive. ${ }^{37}$ More accurately, these cases deny $\mathrm{P}$ a right of action unless the state in which he is injured would permit him to maintain an action there against a personal representative there appointed and also the state in which he sues permits a cause of action in tort for personal injuries inflicted in that state to survive against a locally-appointed personal representative of the deceased tort-feasor. On the authority of Ormsby v. Chase,

35. 65 F.2d 521, 522 (1933).

36. 290 U.S. 387,388 (1933).

37. Gray v. Blight, 112 F.2d 696 (10th Cir. 1940) ; Woollen v. Lorenz, 98 F.2d 261 (D.C. Cir. 1938); Muir v. Kessinger, 35 F. Supp. 116 (E.D. Wash. 1940); Dougherty v. Gutenstein, 10 F. Supp. 782 (S.D.N.Y. 1935). 
these courts have held that if the cause of action abates in State $X$ because of the death of the alleged tort-feasor, it must abate elsewhere, but even if it does not abate in State $X$, State $F$ need not permit suit on the foreign cause of action against its locally-appointed personal representative. The American Law Institute is in accord, ${ }^{38}$ as is some state authority. ${ }^{39}$

A plausible argument can be made in support of these cases. Suppose State $X$ does have a survival statute. A judgment recovered there against a locally-appointed personal representative of the deceased tort-feasor is not one that binds such representative to pay out of his own assets. It is not a judgment in personam in substance, but only a judgment that evidences a claim against assets of the decedent which are within the competency of State $X$ for purposes of administration. State $\mathrm{X}$, so the argument may run, lacks power to establish by its legislation claims against assets that are within the competency of State $F$ to administer. It may be, the argument further runs, that if the cause of action of the injured person is abated in State $\mathrm{X}$ by the death of the wrongdoer, it is abated elsewhere; but if it is not so abated in State X, the cause of action will not be recognized in State $F$ against State $F$ assets unless State $F$ has by statute adopted a policy similar to that of State $X$ - unless State $F$ has a statute permitting claims for damages suffered in State $F$ to survive against the deceased wrongdoer's personal representative, appointed in State F.

The argument is vulnerable. Most lawyers are familiar with the statement that descent of land or an immovable is regulated by the law of the location, ${ }^{40}$ and with the statement that, generally speaking, distribution of movables is regulated by the law of the decedent's last domicil. ${ }^{41}$ It is also said frequently that descent and distribution of the assets of a decedent are not matters of federal regulation. What is meant, of course, is that the descent and distribution of the net assets of a decedent are not matters of federal regulation. Whether or not a claim is to be recognized and enforced as a valid charge against gross assets may not be a matter to be regulated by state law alone. State power in the administration of the assets of a deceased is subject to certain limitations imposed by the Constitution of the United States.

Priority of claims against the assets of $D$ is not wholly a matter of state law. A debt due the United States may be subject to the priority of an earlier valid and specific lien on D's assets that was

38. Restatement, Conflict of Laws, $\$ 390$, comment $b$ (1934).

39. E.g., Herzog v. Stern, 264 N.Y. 379, 191 N.E. 23 (1934), cert. denied, 293 U.S. 597 (1934).

40. Restatement, Conflict of Laws, $\$ 245,249$ (1934).

41. Id. $\S \S 303,306$. 
perfected before the debt to the United States accrued. ${ }^{42}$ Priority for a debt due the United States may also be subordinated to the reasonable costs of administration, ${ }^{43}$ funeral expenses, ${ }^{44}$ and a widow's or child's award. ${ }^{45}$ In general, however, priority for debts due the United States is secured by federal statute. ${ }^{46}$

If priority of debts is not wholly a matter of state law, may the establishment of claims against assets within the competency of State $F$ to administer be a matter not wholly for the law of that state to decide? For example, suppose a valid money judgment is recovered in State $\mathrm{X}$ against a defendant, and an action in State $\mathrm{F}$ is brought by the judgment creditor on the judgment against the judgment debtor. The court in State $F$ probably would be under a duty, by virtue of the full faith and credit clause, to give effect to that judgment as an adjudication of a right-duty relation between the judgment creditor and the debtor. ${ }^{47}$ The court in State $F$ could not refuse to do so merely because it could have refused to allow suit on the original cause of action for reasons of its own local public policy. ${ }^{48}$ Suppose that no action is brought in the lifetime of the judgment debtor on the judgment recovered in State $X$, but the judgment remains unsatisfied at the time of the latter's death and is still enforcible, i.e., action thereon is not barred by any statute of limitations of either State X or State F. In proceedings in the court in State $F$ in which assets of the deceased judgment debtor are being administered, the judgment would have to be given recognition as an adjudication of a right-duty relation between the judgment creditor and the debtor. Again, the court in State F could not refuse to grant such recognition on the ground that, for reasons of its own local public policy, it could have refused to allow suit on the original cause of action. The full faith and credit clause forbids such a refusal. ${ }^{48}$

To summarize, in our hypothetical case 2 the conduct of $D$ while he was present in person in State $X$ might have been the basis of a judgment against him in State $X$ in his life. Had such a judgment

42. See statements in United States v. Guaranty Trust Co., 33 F.2d 533, 536 et seq. (8th Cir. 1929), aff'd, 280 U.S. 478 (1929).

43. See statement in case of Jessie Smith, 24 B.T.A. 807, 811 (1931).

44. See statement in Postmaster Gen. v. Robbins, 19 Fed. Cas. 1126 (D. Me. 1829), cited in G.C.M. 4217, VII-2 Cum. Bull. 162 (1928) and in S.M. 5032, V-1 Cum. Bull. 109 (1926).

45. Jessie Smith, 24 B.T.A. 807 (1931). See also I.T. 2712, XII-2 Cum. Bull. 138 (1933); but cf. May R. Kieferdorf, 1 T.C. 772 (1943).

46. REv. STAT. \$3466 (1875), 31 U.S.C. \$ 191 (1948).

47. See statement of Mr. Justice Douglas in Williams v. North Carolina, 317 U.S. 287, 294-5 (1942).

48. Fauntleroy v. Lum, 210 U.S. 230 (1908).

49. Rights of priority in payment, of course, are another matter. 
remained unsatisfied at his death, and had action thereon not been barred by any statute of limitations of State $F$, in an action by $P$ against the administrator of $D$ appointed in State $F$, the court of State F would be compelled by full faith and credit to recognize the judgment as an adjudication of a right-duty relation between $P$ and $D$ as a basis for a claim against the assets of $D$ which were being administered in State F. Assume that no action in case 2 is brought in State $\mathrm{X}$ against $\mathrm{D}$ in his lifetime. State $\mathrm{F}$ could develop its conflict of laws rules in such manner as to lead its courts to recognize the survival statute of State $\mathrm{X}$ as a basis for allowing a claim against the assets of $D$ in State F. ${ }^{50}$ Full faith and credit should require it to do so. Such compulsion would not interfere with State F's peculiar governmental interest in regulating descent and distribution of D's assets.

\section{Jurisdiction over the Foreign Personal Representative OF A NON-RESIDENT MOTORIST}

If in case 2 a court in State $F$ is under a duty to grant, to the extent just indicated, full faith and credit to the survival statute of State $\mathrm{X}$, the question will next arise whether the personal representative of $D$ lawfully appointed in State $F$ may be successfully sued in State X.

Case 3. D, a resident of State $F$, by negligent driving of his car in State $X$, injures $P . D$ dies before $P$ brings action. $A$ is appointed personal representative in State $F$. State $X$ has a statute permitting causes of action for personal injuries to survive the death of a tortfeasor. It also has a statute providing that its courts shall have jurisdiction of an action against the personal representative of a nonresident motorist for the recovery of compensation for personal injuries caused by the non-resident's negligent operation of a motor vehicle in State X. ${ }^{51}$ The statute is purportedly drawn on the theory that a non-resident motorist by his use of the public highways of State $X$ consents irrevocably to appoint some official of State $X$ as his agent for the receipt of service of process in any action in a court of State $X$ to recover damages for injuries caused by the non-resident motorist's negligent driving on the public highways of State X. Further, the statute is drawn on the theory that a non-resident undertakes

50. See Chubbuck v. Holloway, 182 Minn. 225, 234 N.W. 314, rev'd on other grounds, 234 N.W. 868 (1931). See also: In re Daniel's Estate, 208 Minn. 420, 294 N.W. 465 (1940); Kertson v. Johnson, 185 Minn. 591, 242 N.W. 329 (1932); Burg v. Knox, 334 Mo. 329, 67 S.W.2d 96 (1933) semble; Parsons v. American Trust \& Banking Co., 168 Tenn. 49, 73 S.W.2d 698 (1934); 21 Tenn. App. 202, 108 S.W.2d 187 (1937).

51. E.g., N.Y. VEHICLE \& TrafFic LAW $\$ 52$. 
to subject not only himself but his personal representative to the jurisdiction of the courts of State X.

First, suppose $A$ is actually served with process in State $X$ and judgment is entered against him there. It seems that full faith and credit will compel the courts of State $F$ to give effect to such judgment as a claim against D's assets subject to administration in State $F$.

In Knoop v. Anderson ${ }^{52}$ the court thought that an administrator appointed in State $F$ could be sued in State $X$ only if there were assets of $D$ in State $X$; that a judgment against $A$ as administrator appointed in State $F$ could not be a judgment in personam against him; that the most the courts of State $X$ could do would be to enter a judgment against $A$ which would in substance be an adjudication of a claim to be satisfied out of the assets of $D$ in State $X$; that State $X$ courts could not establish a claim against assets of $D$ unless the assets were within the competency of State $\mathrm{X}$ to administer.

Granted, it would violate due process for State $\mathrm{X}$ to enter a judgment against the State $F$ administrator which would undertake to bind him in personam. There is no need to discuss the power of State $X$ by means of an action against the State $F$ administrator to establish a claim against assets of the deceased in State X. Normally an administrator would be appointed in State $X$ to administer assets there, but there would seem to be no reason why State $X$ should not treat one appointed administrator in State $F$ as if he also had been appointed administrator in State $X .{ }^{58}$

The critical question is whether State $X$ can by action brought against the State $F$ administrator on personal service in State $X$ adjudicate in favor of the plaintiff a claim to share in State $F$ assets. Is State $F$ under full faith and credit obliged to give recognition to such adjudication?

Morris $v$. Jones ${ }^{54}$ may afford help by furnishing an analogy. Chicago Lloyds was an association ${ }^{55}$ authorized to carry on an insurance business in Illinois and elsewhere. It obtained a license to conduct business in Missouri, where Morris brought an action in tort against it. During the pendency of the suit the Illinois Director of Insurance was appointed by an Illinois court to take possession of the assets of the association and to liquidate it. The Illinois court fixed

52. 71 F. Supp. 832 (N.D. Iowa 1947).

53. E.g., cf. In. Rev. Stat. c. 3, $\$ 416$ (1951).

54. 329 U.S. 545 (1947).

55. Although Chicago Lloyds was described in different terms by the majority and by the dissenters, it is clear that the concern comprised a group of persons who enjoyed special privileges under the Illinois Insurance Code of 1937, ILL. LAwS 1937, pp. 696 et seq. Pertinent sections are now found in ILL. REv. STAT. c. 73, \$698 et seq. (1951). 
a day for filing of claims and ordered all suits pending against the association stayed. Counsel for the association in Morris' Missouri suit thereupon withdrew from the case, and the Missouri court was advised of the appointment of the Illinois liquidator and the consequent vesting of title in him to all the assets of Chicago Lloyds. ${ }^{58}$ The Missouri court, however, allowed Morris to recover a judgment against Chicago Lloyds for $\$ 50,000$. He then presented the judgment as a claim in the liquidation proceedings in Illinois. The Illinois liquidator refused to recognize the judgment as a claim, and the Supreme Court of Illinois upheld his action. ${ }^{57}$ The Supreme Court of the United States held that under the full faith and credit clause the Missouri judgment was entitled to recognition in the Illinois liquidation proceedings as a claim against assets. The Missouri judgment did not purport to divest the association of its legal relations with reference to any specific part of its assets. ${ }^{58}$ The Illinois official liquidator was vested with title to assets in Illinois of the association. ${ }^{59} \mathrm{He}$ was under a duty to use such assets in payment of claims against Chicago Lloyds. ${ }^{60}$ The Supreme Court decision required him to admit the Missouri judgment against the association as a claim.

The case is an interesting illustration of the workings of full faith and credit. Had a judgment been recovered in Illinois against the association after the appointment of the Illinois liquidator, it seems that the judgment would not have been a provable claim in the Illinois liquidation proceedings. ${ }^{61}$ Also, a judgment in Missouri against an Illinois association in liquidation in Missouri would not be a provable claim in Missouri liquidation proceedings. $^{62}$ And yet the judgment

56. See Ill. Rev. Stat. c. 73, \$803 (1951).

57. People ex rel. Jones v. Chicago Lloyds, 391 Ill. 492, 63 N.E.2d 479 (1945).

58. Morris v. Jones, 329 U.S. 545, 548, 549 (1947).

59. Id. at 548 .

60. See Ill. Rev. Stat. c. 73, \$805 (1951).

61. See People ex rel. Jones v. Chicago Lloyds, 391 I11. 492, 507, 508, 63 N.E.2d 479, 486, 487 (1945) ; see statement of Mr. Justice Douglas that "It is no more important that the suit on this underlying claim could not have been maintained in Illinois after the liquidator had been appointed than the fact that a statute of limitations of the State of the forum might have barred it." Morris v. Jones, 329 U.S. 545,551 (1947). Compare this statement with the statement of Mr. Justice Frankfurter that "Concededly, after the title to the Illinois assets of Chicago Lloyds has passed to the Illinois liquidator, it would not be open to a citizen of Illinois to obtain in the courts of Illinois, so as to serve as a basis of a claim in Lloyds Illinois assets, such a judgment as Morris, a citizen of Missouri, secured in the Missouri courts." Id. at 557-558.

62. See McDonald v. Pacific States Life Ins. Co., 344 Mo. 1, 124 S.W.2d 1157 (1939), cited in People v. Chicago Lloyds, 391 Iil. 492, 507, 63 N.E.2d 479, 487 (1945). And note the following statement by Mr. Justice Douglas: "And the Missouri judgment may not be defeated by virtue of the fact that under other circumstances petitioner might not have been able to obtain it in Missouri or to have received any benefit from it there, as, for example, if a liquidator had been appointed for the debtor in Missouri prior to judgment." Morris v. Jones, 329 U.S. 545,551 (1947). 
recovered in Missouri after title to Illinois assets had vested in the Illinois liquidator is held entitled to recognition as a claim against assets of the association which, undoubtedly, Illinois alone had jurisdiction to administer in liquidation proceedings.

The decision has been criticized by eminent authority as an instance of "full faith and credit out of hand." ${ }^{83}$ It is submitted, with due deference, that the case is an instance where full faith and credit compels recognition in Illinois of a Missouri judgment because of a superior interest in Missouri. Morris, a resident of Missouri and a Missouri agent for Chicago Lloyds, was, in Missouri, wrongly arrested and maliciously prosecuted. ${ }^{64}$ May not the State of Missouri, of all the states, have had a special governmental interest in determining whether and to what extent Morris should be granted reparation against Chicago Lloyds? Missouri lacks power to administer in liquidation the Illinois assets of Chicago Lloyds. That power is in the Illinois liquidator appointed by order of a competent court in Illinois. Illinois has a special governmental interest in the liquidation and administration of the assets in Illinois. Morris $v$. Jones, as finally decided in the Supreme Court, requires Illinois to recognize the superior interest of Missouri in determining or adjudicating that Morris had a claim for compensation against Chicago Lloyds. The Supreme Court assures implementation of the Missouri interest by holding that full faith and credit requires Illinois to recognize the Missouri judgment as a claim against Illinois assets.

In Morris $v$. Jones it is true that Chicago Lloyds was subject to the judicial power of Missouri before the Illinois court entered the decree for its liquidation. The Missouri judgment may have been a judgment in personam against the association. ${ }^{65}$ Under the law of Illinois the association as some sort of entity may be said to have continued after the entry of the decree for liquidation. ${ }^{68}$ The entity

63. Harper, The Supreme Court and the Conflict of Lazes, 47 CoL. L. REv. 883, 884 et seq. (1947).

64. See Petition in case of Morris v. Associated Underwriters, Inc., 206424B, on file with Clerk of the Circuit Court, City of St. Louis, Missouri.

65. Mr. Justice Douglas points out that "the Illinois Supreme Court did not hold that the appointment of a liquidator for Chicago Lloyds operated as an abatement of the suit" brought by Morris in Missouri. Morris v. Jones, 329 U.S. 545, 550 (1947). Mr. Justice Frankfurter says: "We are concerned here solely with the situation presented by a State's exercise of its power over the liquidation of the assets of an insurance company of its own creation. . . . We must assume it to be Illinois law that the power to pass upon claims against property of a defunct Illinois insurance company is lodged in the liquidator and that such power is not to be foreclosed by a judgment against the defunct concern after title passes to the liquidator." Id. at 557.

66. As to this, the opinion of the Supreme Court of Illinois is not clear. See statement of Mr. Justice Frankfurter that "What is relevant also is whether in such liquidation proceedings Illinois can refuse to accept at face value a judgment against an Illinois insurance company obtained after that company had ceased to exist, a 
was hardly a vigorously living organism. In our hypothetical case 3 it is true that D was not subjected in his life to the judicial power of State $\mathrm{X}$. In Morris $v$. Jones a Missouri judgment in personam against Chicago Lloyds is given recognition as a claim against assets in liquidation in Illinois. ${ }^{67}$ In our hypothetical case 3 State $\mathrm{X}$ cannot give a judgment in personam against $A$ that will ground a claim against assets in administration in State $F$.

Nevertheless we contend that if in Morris $v$. Jones full faith and credit requires the Missouri judgment to be recognized as a claim against Illinois assets of Chicago Lloyds, full faith and credit should require the State $\mathrm{X}$ judgment in our hypothetical case 3 to be recognized as a claim against assets of $D$ in State $F$. The Illinois liquidator of Chicago Lloyds was an officer appointed by an Illinois court to administer the assets in Illinois of a group of persons which had obtained certain privileges under the law of Illinois. Missouri could not have given a judgment against Chicago Lloyds which would alter the legal relations of the Illinois liquidator with reference to the assets in Illinois to which he had title. ${ }^{68}$ In case $3, \mathrm{~A}$ as administrator of $\mathrm{D}$ is an official appointed in State $F$ to liquidate and dispose of certain assets of $D$, in whom as one of its residents State $F$ had a particular interest. Disposition on D's death of those assets, after payment of claims, will be had according to the law of State F. ${ }^{69}$ The persons entitled to take thereunder may or may not be State $F$ residents. Whether or not they are is immaterial. They should take in subordination to those who are adjudged in the courts of State $F$ to have claims for compensation against the assets of $D$ because of wrongful acts committed by $\mathrm{D}$ in his lifetime in State $\mathrm{X}$-to claims of "creditors of the estate," to use popular phraseology. On reasonable analogy to Morris v. Jones the claims of such "creditors" could be grounded on adjudications rendered by courts in a state that cannot itself administer the assets of $\mathrm{D}$.

$U_{p}$ to the present it has been assumed that, in our hypothetical case $3, A$ was served with process in State $X$. If the judgment against

judgment which the creditor would enforce against assets which passed to the State before the judgment was obtained," Id. at 560 (emphasis added); and his statement that "Whether recovery may be based on this judgment in Missouri, or in any other State except Illinois, or even in Illinois should the assets go out of the State's hands and return to a reaminuted Chicago Lloyds, are questions that do not now call for consideration." Id. at 565 (emphasis added).

67. "In any event, the Missouri judgment is res judicata as to the nature and amount of petitioner's claim as against all defenses which could have been raised." Id. at 552 .

68. "No one can obtain part of the assets or enforce a right to specific property in the possession of the liquidation court except upon application to it." Id. at 549.

69. This is so as to such assets as are within the jurisdiction of State $F$ to administer. 
him in State $\mathrm{X}$ as D's personal representative is entitled in State $\mathrm{F}$ to full faith and credit as a claim against D's assets, it would seem that the State X judgment should be equally entitled to full faith and credit in State $F$ if $A$ were brought before the State $X$ court only by substituted service on some state official of State X.

Finally it beclouds the issue to say that $A$ as administrator or executor of D's estate under a State $F$ appointment cannot be sued outside the state of his appointment. Statements to that effect are made over and over again. The theory that a personal representative cannot be sued outside the state of his appointment rests largely, in this country, on Vaughan $v$. Norihup. ${ }^{70}$ In that case an administrator appointed in Kentucky, the state in which his decedent died domiciled, was sued in the District of Columbia by certain persons claiming as next of kin, who sought to force distribution of a sum of money the administrator had received from the federal government in satisfaction of a claim of the decedent for services rendered in the Revolution. In his opinion Mr. Justice Story does speak of "an established doctrine, that an administrator, appointed in one state, cannot, in his official capacity, sue for any debts due to his intestate in the courts of another state; and that he is not liable to be sued in that capacity, in the Courts of the latter, by any creditor, for any debts due there by his intestate." $\mathbf{7 1}$ It is undoubtedly this statement that has led courts and commentators to cite the case as authority that an administrator appointed in one state cannot be sued as such in the courts of a sister state. ${ }^{72}$

Due attention has not, perhaps, been given to the fact that in the course of his opinion Mr. Justice Story makes it plain that the decision was rendered in the light of consideration of the interests of the federal government. The complainants had urged that, because the Kentucky administrator had received payment from the treasury at Washington, such payment constituted assets of the deceased within the District of Columbia, and the Kentucky administrator was to be held to account for them in the District. To this Mr. Justice Story replied that as a debtor the United States was not to be regarded as domiciled in the

70. 15 Pet. 1 (U.S. 1841).

71. $I d$. at 6 .

72. E.g., Lewis v. Parrish, 115 Fed. 285, 287 (2d Cir. 1902) ; Bowles v. R. G. DunBradstreet Corp., 25 Del. Ch. 32, 45, 12 A.2d 392, 398 (1940); Burton v. Williams, 63 Neb. 431, 434-435, 88 N.W. 765, 766-767 (1902); GoodrICH, Conflrct of Laws 562 (3d ed. 1949) ; Stumberg, Conflict of Laws 445 (2d ed. 1951). However, certain exceptions to the general rule have long been recognized, particularly the exception that allows equitable relief against a defaulting foreign personal representative; so even before Vanghan $v$. Northup, supra note 70 , a New York court held that it could require an accounting of an Irish administrator who had brought assets of his intestate into New York and there misapplied the same. McNamara v. Dwyer, 7 Paige Ch. 239 (N.Y. 1838). And see Falke v. Terry, 32 Colo. 85, 75 Pac. 425 (1903). 
District so that debts due from the United States to a decedent would be assets for administration only in the District. On the contrary, the interests of the federal government were deemed to require that the United States be permitted to pay to the domiciliary (Kentucky) administrator a debt due the deceased. Said the Justice:

". . . the administrator of a creditor of the government, duly appointed in the state where he was domiciled at his death, has full authority to receive payment, and give a full discharge of the debt due to his intestate, in any place where the government may choose to pay it; whether it be at the seat of the government, or at any other place where the public funds are deposited. If any other doctrine were to be recognized, the consequence would be, that before the personal representative of any deceased creditor, belonging to any State in the Union, would be entitled to receive payment of any debt due by the government, he would be compellable to take out letters of administration in this District for the due administration of such assets. Such a doctrine has never yet been sanctioned by any practice of the government; and would be full of public as well as private inconvenience." (emphasis added). ${ }^{73}$

If the domiciliary administrator were the proper person to receive payment, and if personalty of the deceased intestate were to be distributed in accord with the statute of distributions of Kentucky as the state of the latter's last domicile, considerations of convenience and expediency might well be held to require that suit by next of kin to compel distribution be brought in the state of such domicile. Such was the conclusion of the Supreme Court.

Mr. Justice Story referred to a statute of Congress that permitted an administrator appointed outside the District of Columbia to sue in the District on a claim alleged to be due the deceased. ${ }^{74}$ The failure of the statute to provide that such a foreign administrator should be subject to suit in the District was regarded as equivalent to a declaration that he was not, but there is not a word to the effect that Congress could not have so provided. There was no reason why the Court in Vaughan $v$. Northup should have expressed an opinion on the power of Congress so to provide. All that is contended is that there is no support for the proposition that the Court in the case committed itself to holding that Congress could not so enact.

In fact, under its power to establish inferior federal courts Congress may provide that administrators and executors be subject to suit in federal courts in states other than the states of their appointment. ${ }^{75}$

73. Vaughan v. Northup, 15 Pet. 1, 6-7 (U.S. 1841).

74. 2 StaT. 758 (1812).

75. United States v. Union Pacific R.R., 98 U.S. 569 (1878). 
It may be that this power must be exercised so as not unreasonably to interfere with the administration and settlement of estates of decedents in the state probate courts. ${ }^{70}$ In 1921, a federal statute was passed which permitted in any suit in the federal courts the revival of action against "executors and administrators of any party, who dies before final judgment or decree, appointed under the laws of any State or Territory of the United States. . . . " 77 Under this statute a federal district court in Wisconsin revived a suit against the Missouri administrator of Hermann, a deceased Missourian, even though the outcome of the suit might have led to the imposition of a constructive trust on assets in the hands of the Missouri administrator-assets for which he would otherwise have accounted to the Missouri court of probate. ${ }^{78}$

Whether or not an action may be revived against the personal representative of a defendant who dies pending suit has been described as a "procedural" question, one to be settled by the statutory or other law of the state in which the action is pending, without reference to the law of the state in which the cause of action arose. ${ }^{79}$ Generally the personal representative against whom revival is sought is one appointed and qualified in the state in which the action is pending. For example, $D$ (a domiciliary of State $Y$ ) by his negligent acts committed in State $X$ physically injures $P$ in State $X ; P$ sues $D$ in State $Y$, and $D$ dies pending the action. Whether or not revival is to be allowed against $A$, appointed as D's administrator in State $Y$, is to be settled, it has been said, in accord with the "local" law of State $Y$, without reference to the law of State $X .^{80}$ Suppose that action is pending against $D$ in State $\mathrm{X}$ at the time of his death and he died domiciled in State $\mathrm{Y}$, leaving no assets or estate for administration in State $X$. To date, what authority there is in the state courts seems to militate against allowing revival against the administrator or executor appointed in State Y.81

\section{Cf. Anderson v. Yungkau, 329 U.S. 482, 486 (1947).}

77. 42 Stat. 352, 353 (1922), amending Rev. Stat. \$955 (1875); 28 U.S.C. $\S 778$ (1928). The statutory provision has been superseded by Rule 25 of Federal Rules of Civil Procedure.

78. Luster v. Martin, 58 F.2d 537 (7th Cir. 1932), cert. denied, 287 U.S. 637 (1932). It should be noted that a United States District Court in Wisconsin had enjoined Hermann and his agents from disposing of certain assets and that the Circuit Court of Appeals said: "The executors succeeded to the estate of the deceased Hermann. That estate was subject to certain liens, among them being the burden of the trust in favor of the stockholders." Id. at 541 (1932). But see comments on the case in Commercial Solvents Corporation v. Jasspon, 92 F. Supp. 20, 23-24 (S.D.N.Y. 1950). See also Plimpton v. Mattakeunk Cabin Colony, 6 F. Supp. 72 (D. Conn. 1934).

79. See statements in Orr v. Ahern, 107 Conn. 174, 176, 139 Atl. 691,692 (1928).

80. Ibid.

81. See discussion in Knoop v. Anderson, 71 F. Supp. 832 (N.D. Iowa 1947). 
Whether the action can be revived against $A$ as a State $Y$ administrator or executor really raises the same question of power in State $\mathrm{X}$ as does the question whether $\mathrm{A}$ as a State $\mathrm{Y}$ administrator could have been sued in State $X$ as the original party defendant. Nothing is gained by terming "survivorship" a matter of "substance" and "revival" a matter of "procedure" or "remedy." In both cases the question is whether State $X$ can exert judicial power over $A$ as an administrator appointed and qualified in State $Y$.

Congress may provide for actions against personal representatives in federal courts outside of the states of their appointments. Also, an administrator or executor may find himself substituted as a party defendant in some action pending in a federal court outside the state of his appointment. It does not necessarily follow that a personal representative may be subject to suit against his will and without his consent in the court of a state outside the state of his appointment. The situation in the federal courts, however, has a certain persuasive force as to what should be allowed in the state courts. The Constitution envisages at least the possibility of an efficient system of federal courts which will render uniform justice throughout the United States. The Constitution also contemplates a system of courts in the states manned by judicial officers appointed under state law and operating under procedures prescribed by the states, subject to certain restrictions imposed by the Constitution-those of due process and others. The Constitution contemplates that each state in its administration of justice shall bear in mind that it is one of a sisterhood of forty-eight states, each charged with the task of making its state-administered system of justice effectively operative within the frame of a federal union, with due regard to the claims and interests of the sister states. This on occasion may require a state to give effect within its own borders to the statutory policy of a sister state. On occasion, when a state does not choose to do so, the Supreme Court under the full faith and credit clause may require it to subordinate its peculiarly local interests to the superior interests of a sister state. It is submitted that a statute providing for the exercise of judicial power over the personal representative of a deceased non-resident motorist is an instance when full faith and credit should so operate. 